\title{
A Case of Saddle Nose Deformity Caused by Electrocautery of Nasal Septum
}

\author{
Seung Min In and Jong Yeup Kim \\ Department of Otorhinolaryngology-Head and Neck Surgery, Konyang University College of Medicine, Daejeon, Korea
}

\section{비중격의 전기소작술 후 발생한 안장코 1예}

인 승 민·김 종 엽

건양대학교 의과대학 이비인후-두경부외과학교실

\author{
Received November 26, 2016 \\ Revised March 9, 2017 \\ Accepted March 10, 2017 \\ Address for correspondence \\ Seung Min In, MD, PhD \\ Department of Otorhinolaryngology- \\ Head and Neck Surgery, \\ Konyang University \\ College of Medicine, \\ 158 Gwanjeodong-ro, Seo-gu, \\ Daejeon 35365, Korea \\ Tel +82-42-600-9215 \\ Fax $+82-42-543-8959$ \\ E-mail ismi96@hanmail.net
}

Electrocautery of nasal septum is a very common treatment of epistaxis in Otorhinolaryngology. However, serious complications of electrocautery are rare. We encountered a 52-year-old female patient who presented with nosebleeds. A definite focus of bleeding was identified by nasal endoscopy, thus electrocautery by bipolar diathermy was performed in the area of Kisselbach's plexus of nasal septum. There were no abnormal findings in the nasal septum during the three weeks of outpatient visit. However, the patient noticed a depression near the tip of her nose 12 weeks later. Saddle nose deformity after electrocautery has not yet reported in the literature. Therefore, we present this case with a brief review of literature.

Korean J Otorhinolaryngol-Head Neck Surg 2018;61(10):532-5

Key Words Electrocagulation · Epistaxis · Nose deformity.

\section{서 론}

비출혈은 매우 흔한 질병으로서, 전 인구의 $10 \%$ 가 심각할 정도의 비출혈을 경험하는 응급질환 중 하나이다. 대부분의 비출혈은 키셀바흐 부위(Kiesselbach's plexus)를 비롯한 전 방에서 발생하며 보존적 치료로 쉽게 지혈이 가능하지만 드 물게 입원 치료를 요하는 다량의 출혈 양상을 보이기도 한다. 전방출혈의 경우에는 질산은 같은 화학물질을 이용한 소작 법, 전기소작법, 전비강패킹으로 대부분 해결이 된다. 이 중 전 기소작법은 가장 흔하게 전방 비출혈의 치료에 이용되는 방법 중 하나로서, 비중격의 출혈이 있는 주변 혈관을 레이저나 전 기소작기를 이용하여 소작하는 방법이다. 이러한 소작법은 지 나치게 여러 번 하거나 양측 소작 시 비중격 천공의 위험성이

This is an Open Access article distributed under the terms of the Creative Commons Attribution Non-Commercial License (https://creativecommons.org/licenses/by-nc/4.0) which permits unrestricted non-commercial use, distribution, and reproduction in any medium, provided the original work is properly cited.
알려져 있다. 하지만 아직까지 비중격 소작 후 발생한 안장코 에 대한 보고는 없었다. 본 증례에서는 전방 비출혈로 진단되 어 외래에서 bipolar diathermy(ValleyLab; Tyco, Gosport, $\mathrm{UK}$ )를 이용한 전기소작법으로 성공적인 치료 후, 외래 추적 관찰 중 비중격의 천공, 혈종, 농양 등의 병변 없이 발생한 안 장코 변형을 경험하였다. 이에 저자들은 경험한 증례의 가능 한 원인과 기전에 대하여 문헌 고찰과 함께 보고하는 바이다.

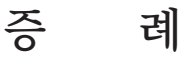

52세 여자가 내원 5일 전부터 반복되는 우측 비출혈을 주 소로 내원하였다. 비출혈은 주로 코를 풀 때 간헐적으로 났으 며, 수 분간 출혈이 지속되다 저절로 멈추는 양상으로 반복되 었다. 이전에 특별한 외상이나 비출혈의 과거력은 없었고, 가 족력이나 출혈경향성 질병도 없었으며, 복용하는 약물도 없 다고 하였다. 외래에서 시행한 비내시경상 우측 비중격의 키셀 
바흐 혈관총 부위의 돌출된 혈관이 보이는 전형적인 전방 비 출혈의 소견으로 확인되어(Fig. 1), 비중격의 부분 마취하에 내시경을 이용하여 비중격 전방부의 키셀바흐 혈관총 부위 의 돌출된 혈관 부위에 30 watts로 전기소작술을 bipolar diathermy 기구를 이용하여 수차례 시행하였다. 소작 시행 중 출혈이 있어서 출혈부위 중심으로 원위부에서 근위부쪽으로 10 차례 정도의 추가적인 소작술을 시행하였다. 성공적으로 전 기소작술을 시행한 후, 더 이상의 출혈이 없음을 확인한 후, 지혈 부위에 안연고를 도포하고 치료를 종료하였다. 환자에 게 코피 지혈 후 주의사항을 설명하고, 재방문을 권유하였다. 환자는 일주일 후 외래에 방문 하였으며, 재출혈은 없었고 가 끔씩 시술부위가 따가운 느낌이 있다고 호소하였다. 비내시경 상 전기소작을 시행한 비중격 부위에 누런 갈색의 가피가 보이 는 통상적인 전기소작 시술 후의 소견이었다. 향후 특별한 불 편감이나 재출혈 시 재방문을 권유하였으며, 치료를 종료하였 다. 환자는 마지막 방문 2주 후에 지속되는 우측 비강 및 비강 상부 통증을 주소로 외래로 다시 내원하였으며, 비내시경 소 견은 우측 비중격 전기소작부위에 아직 누런 가피 및 궤양성 점막이 확인되었다(Fig. 2). 이에 저자는 비중격의 천공, 비중격 연골염 등 이차 감염 등의 가능성을 고려하여 비내시경으로 비중격을 관찰하고 직접 비중격을 촉지하였으나, 정상적인 연

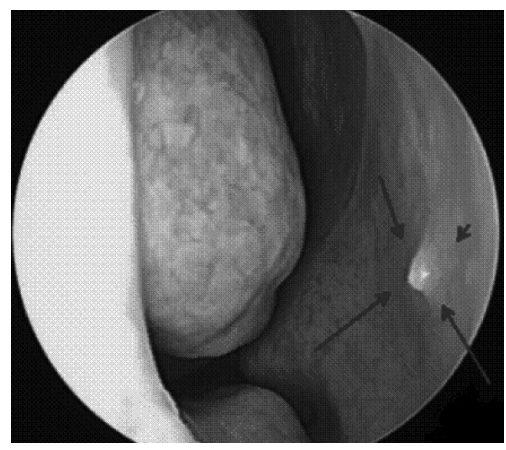

Fig. 1. Preoperative endoscopic finding. Engorged vessel in the area of Kisselbach's plexus of right nasal septum was identified (blue arrows).

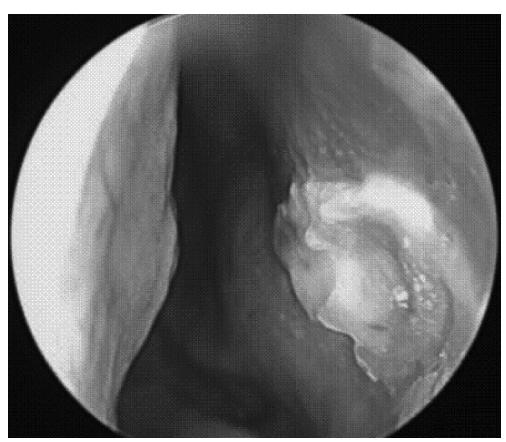

Fig. 2. Postoperative 3 weeks endoscopic finding after electrocautery. Ulcerative mucosa of right nasal septum was coated with yellowish crust.
골이 촉지되었고 비중격 혈종, 농양이 의심되는 소견은 없음을 확인하였다. 진찰 후 환자에게 비중격의 이차적인 감염 및 비 중격 연골염을 의심하여 2세대 세파 항생제 및 비스테로이드 성 소염제를 처방하고 항생제 안연고를 시술부위에 도포하 도록 교육하고 경과관찰을 위해 5일 후 재방문을 권유하였다. 재방문 시 시행한 비내시경상 우측 비중격 점막의 병변부위는 호전 중인 양상을 보였으며, 촉진 시 점막과 연골 모두 정상소 견이었으며, 비배부에도 발적성 병변은 관찰되지 않았다. 그 러나 환자는 아직 비강상부 통증이 남아 있다고 호소하였다. 이 에 저자는 비내시경상 비중격이 정상적 소견이며, 촉진상에도 정상적으로 비중격이 만져지고 외비에도 특별한 소견이 관찰 되지 않아 환자를 안심시킨 후 전과 같은 약을 5일 처방 후 통 증의 경과관찰 및 $\mathrm{CT}$ 등 추가검사의 필요성을 설명하고 일주 일 후 재방문을 권유하였다. 이후 환자는 자의적으로 외래 경 과관찰을 중단하였으며, 마지막 방문 45일 후 비배부의 변형 을 주소로 외래에 방문하였다. 비내시경 소견상 비중격 천공이 나 혈종, 농양 소견이 없는 정상적인 소견을 보였으며(Fig. 3), 이학적 검사상 외비는 비배부 즉, keystone 영역이 주저앉은 전형적인 안장코 소견을 보였다(Fig. 4). 시행한 CT상 정상적인

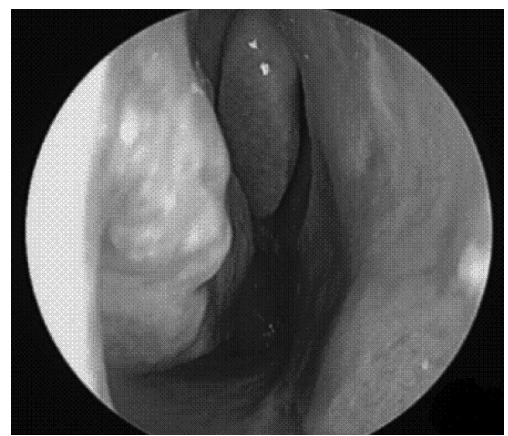

Fig. 3. Postoperative 12 weeks endoscopic findng. There were no abnormal findings in the electrocauterized mucosa of right nasal septum.

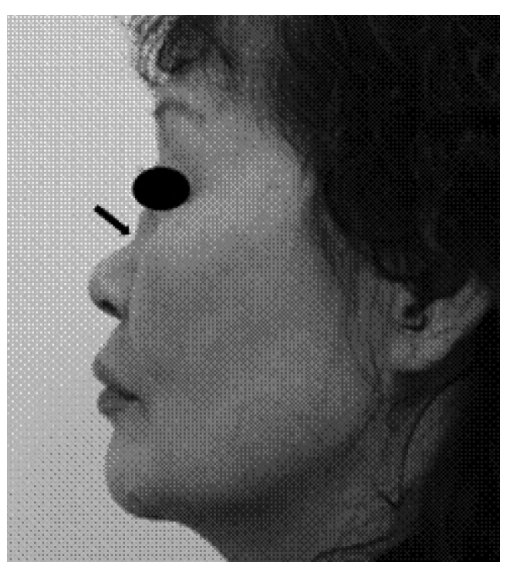

Fig. 4. Lateral view of external nose of a patient 12 weeks after bipolar cautery of nasal septum. The cartilaginous part of the dorsum shows dropping (arrow). 

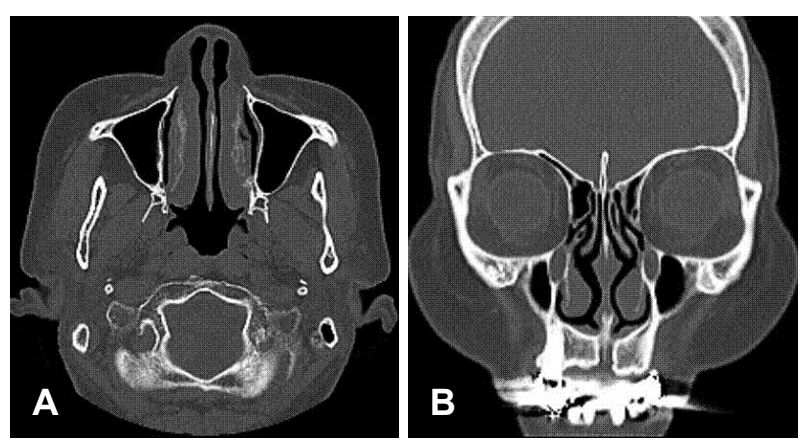

Fig. 5. Axial CT scan (A) and coronal scan (B) demonstrate that there were no abnormal findings of nasal septum.

비중격 소견이었으며, 비중격 농양을 의심할 소견은 없었다 (Fig. 5). 이에 안장코의 원인으로 Wegener's granulomatosis, relapsing polychondritis, syphilis 등의 전신감염성 질환을 배제하기 위해 류마티스 내과와 협진하여 검사를 실시하였 으며, 결과는 모두 정상이었다. 일반혈액 검사와 면역학적 검 사에서 백혈구의 수치가 $7000 / \mathrm{mm}^{3}, \mathrm{C}$-반응성 단백질은 0.4 $\mathrm{mg} / \mathrm{dL}$, 적혈구 침강속도는 $9 \mathrm{~mm} / \mathrm{hr}$ 로 정상범위 소견을 보 였다. 추가적인 면역검사와 다른 부위의 확인을 위하여 흥부 전산화단층촬영과 전신 골스캔을 시행하였으며, 모든 검사 결과는 정상소견을 보였다. 추가로 시행한 면역학적 검사에서 보체 C3, C4 류마토이트 인자, 항핵항체, 항핵세포질항체 및 매독검사에서도 정상범주를 보였다. 시행한 모든 검사 결과에 서 안장코 발생의 뚜렷한 원인은 밝혀지지 않았으며, 외래 진 료과정에서도 비중격의 혈종, 농양 의심소견이 없었으므로 비 중격의 전기소작과 안장코 발생과의 인과관계도 설명되지 않 았다. 이후 외래에서 안장코에 대한 치료로 외비성형술을 권유 하였으며, 안장코 발생 4개월 후 MegaDerm ${ }^{\circledR}$ (L\&C Bio Co., Seongnam, Korea)을 이용한 단순 융비술을 성공적으로 시 행한 후 경과관찰 중이다.

\section{고 찰}

전방 비출혈 치료로 전비강패킹, 질산은 용액을 이용한 화 학적 소작법, 전기소작법이 가장 많이 이용되는 방법이다. 이 와 같은 전방 비출혈 치료 후에 생기는 대표적인 부작용으로 는 재출혈 및 비중격 천공 등을 들 수 있다. 하지만 비출혈의 치료로 시행한 비중격 소작술 이후 발생한 안장코와 같은 외 비변형은 아직까지 문헌에서 보고된 적이 없다. 안장코의 발 생 원인은 외상, 비중격 교정술 같은 의인성 요인, 비중격의 병 변(천공, 혈종, 농양), 육아종성 전신감염질환(베게너 육아종 증, 재발성 다발연골염, 매독) 등이 잘 알려져 있다.1) 또한 비 경결종, 크론병, 타까야수 동맥염, 악성림프종 등 다양한 질 환이 원인으로 보고된다. ${ }^{2,3}$ 본 증례에서 환자는 비중격 수술
을 받은 적이 없고, 특별한 외상의 과거력이 없었기 때문에 외상의 원인은 배제할 수 있었다. 하지만 비중격 소작술도 하 나의 외상 요인으로 작용할 수 있다. 보통의 전기소작술 시에 는 10 20 watts의 전류에너지로 5 6번 정도 비중격의 키셀 바흐 지역의 출혈 지점을 소작하게 된다. ${ }^{4)}$ 하지만 본 증례에 서는 30 watts의 전류로 평소보다 많은 횟수로 소작을 시행 하였다. 이 점이 비중격의 외상으로 작용할 가능성이 있으며, 환자가 더 오랫동안 비중격의 소작부위와 비배부의 통증을 호소한 원인이 아닌가 한다. 또한, 비중격 전기소작 후 3 주째 까지도 비중격 소작부위에 비중격 궤양처럼 헐은 비중격 점 막 소견이 보였었다. 비중격 궤양은 비중격 천공의 선행질환 으로 발생하는 경우가 많으나, 이 환자의 경우 비중격 천공은 발생하지 않았다. 이 점도 평균적으로 비중격 소작술 후 가 피가 1 2주 이내에 호전되는 점을 감안할 때, 비중격 연골과 점막에 손상이 크다는 것을 뒷받침한다. 안장코의 다른 원인 으로 비중격 병변, 즉 천공이나 혈종, 농양을 들 수 있는데, 본 증례에서는 가능한 원인으로 비중격 농양을 들 수 있다. 비중격 농양은 수상 후 10 일 후에 발열, 오한을 동반하며 비 배부 동통과 압통, 전신쇠약감을 동반하나, 이 환자의 경우 비중격 소작부위와 비배부의 동통 외에는 특이 증상이 없었 다. 또한 외래 진찰 시 비내시경상 비중격이 정상적으로 보였 고, 비배부에도 발적이나 감염소견은 없었다. 하지만 본 증례 의 경우, 평소보다 여러 번 소작술을 시행하고, 강한 전류에 너지로 소작술을 시행했으므로 과도한 비중격 전기소작술이 큰 외상으로 작용하였을 가능성이 있다. 과도한 소작으로 인 해 비중격 점막 및 연골이 손상되었고 회복이 지연되면서, 그 에 대한 이차 감염으로 인해 국소적으로 비배부 keystone 지 역의 연골부에 농양이 발생한 가능성을 고려해 볼 수 있다. 농양에 의한 압력과 허혈성 변화에 의해 연골성 비배부에 괴 사성 변화가 시작되고 이차 세균감염이 발생하여 연골의 광 범위한 괴사가 초래되었고, 이로 인한 안장코의 발생을 생각 해 볼 수 있다. Keystone 영역은 비골, 연골성 비중격, 골성 비 중격, 그리고 상외측연골이 연골막과 골막의 단단한 섬유성 연결로 서로 결합되어 있는 부위로 이러한 해부학적 특징 때 문에 일반적으로 비중격 농양이 발생하더라도 주변 구조물 로의 침범 없이 비중격에 국한되어 발생할 수 있다.) 본 증례 환자의 안장코 발생 후, 시행한 단순 융비술 시 keystone 영역 의 비중격 연골은 일부 소실되어 있었으나, 비중격의 미부 및 서골 사골연직판과 맞닿는 비중격 연골은 약간의 위축소견 외에 정상적으로 남아 있는 것이 확인되었다. 이 소견은 국소 적으로 비배부의 keystone 지역의 연골부 농양 발생 가능성 을 뒷받침한다. 본 증례에서는 비중격 농양이 발생한 객관적 증거는 없었으나, 비중격 전기소작술 이후 3 주째까지 통증을 
호소하였는데, 즉시 농양을 의심하고 시험적 천자 시행 및 비 중격 $\mathrm{CT}$ 를 촬영하지 못한 점이 이 증례의 환자 치료의 오점 으로 사료된다. 또 다른 안장코의 발생 원인으로 다양한 전 신 육아종성 감염질환이 있는데, 이 중 가장 가능성이 있는 원 인으로 재발성 다발성 연골염을 생각해 볼 수 있다. 재발성 다 발성 연골염은 전신의 연골조직과 결합조직을 침범하여 파괴 시키는 염증성 질환으로 원인은 분명하지 않으나 자가면역질 환의 일종으로 생각된다. 임상소견으로 이개연골염이 가장 흔 하게 침범하며 비배의 연골에 침범하여 안비변형, 눈을 침범 하여 결막염을 유발하고 관절염과 후두 및 기관지 연골에 침 범하여 호흡부전을 동반하기도 한다. 비연골의 침범 시 비폐 색, 비루, 비출혈이 발생할 수 있으며, 외비의 발적, 부종, 동통 이 생긴 후 안비가 발생할 수 있다. 재발성 다발성 연골염의 진 단은 1976년 O’Hanlan 등이 1) 양측 이개 연골염, 2) 다발 성 관절염, 3) 비연골염, 4) 결막염, 공막염, 각막염, 포도막염 등의 안염증, 5) 후두와 기관연골 등의 연골염, 6) 감각신경성 난청, 이명, 현훈 등의 청각전정기관 손상 등 6가지 진단기준 을 제시하였으며, 이 중에서 3개 이상의 병변이 있으면서 특 징적인 조직병리소견이 있을 때 확진할 수 있다고 보고하였 다. 본 증례의 경우 상기 진단기준에 해당하지 않고 관련 면역 학적 혈청검사상 모두 정상이므로 재발성 다발성 연골염의 가능성은 매우 낮다고 판단된다.

본 증례는 전방 비출혈 치료로 이비인후과에서 흔하게 시 행하는 비중격 전기소작술 시행 후에 안장코가 발생한 첫 증
례 보고이다. 이전 외상의 과거력이 없는 환자가 전방 비출혈 치료로 시행한 전기소작술 이후, 비중격의 천공, 혈종, 농양 발 생 없이 keystone 영역, 즉 비배부의 연골이 녹아서 안장코 가 발생할 수 있음을 보여준 증례로서, 전방 비출혈 시 이비 인후과에서 일상적으로 시행하는 전기소작술 시 전류의 세기 (watts)나 횟수에 세심한 주의를 요할 것으로 판단된다. 또한 본 증례에서처럼, 비중격의 전기소작술 이후 환자가 비중격 의 전기소작부위나 비배부의 통증을 일주일 이상 지속적으 로 호소하는 경우에는 술자는 적극적인 검사와 처치를 고민 해야 하며, 이를 간과할 경우 안장코가 발생할 수 있다는 점 을 고려해야 할 것으로 사료된다.

\section{REFERENCES}

1) Schreiber BE, Twigg S, Marais J, Keat AC. Saddle-nose deformities in the rheumatology clinic. Ear Nose Throat J 2014;93(4-5):E45-7.

2) Merkonidis $C$, Verma $S$, Salam MA. Saddle nose deformity in a patient with Crohn's disease. J Laryngol Otol 2005;119(7):573-6.

3) Shine NP, Hamilton S, McShane DP. Takayasu's arteritis and saddle nose deformity: a new association. J Laryngol Otol 2006;120(1):5962.

4) Johnson N, Faria J, Behar P. A comparison of bipolar electrocautery and chemical cautery for control of pediatric recurrent anterior epistaxis. Otolaryngol Head Neck Surg 2015;153(5):851-6.

5) Kim IS, Chung YJ, Lee YI. An anatomic study on the overlap patterns of structural components in the keystone area in noses of Koreans. Clin Exp Otorhinolaryngol 2008;1(3):158-60.

6) O'Hanlan M, McAdam LP, Bluestone R, Pearson CM. The arthropathy of relapsing polychrondritis. Arthritis Rheum 1976;19(2):191-4. 